\title{
Safety Communication Document
}

National Cancer Institute

\section{Source}

National Cancer Institute. Safety Communication Document. NCI Thesaurus. Code C115726.

Records containing information related to a safety report of a clinical trial. 